\title{
NEMATOLOGY AT THE IMPERIAL COLLEGE OF SCIENCE AND TECHNOLOGY, LONDON
}

$\mathrm{O}$ October 23, at Silwood Park, Sunninghill, the new Shell Parasitology Building was formally handed over to the Imperial College of Science and Technology. A plaque inside the door explains that "These laboratories were erected with the aid of a generous benefaction from Shell International Chem. ical Co., Ltd., in support of research into parasito$\log y^{\prime \prime}$.

The new building consists of two floors, each of 2,400 sq. ft., and a small basement of 400 sq. ft. On the ground-floor are a lecture room and well-equipped teaching laboratory for the one-year postgraduate course in nematology, a preparation room for extracting nematodes from soils or from plant materials, and a radio-tracer room. On the first floor are three staff laboratories, a large laboratory for higher-degree

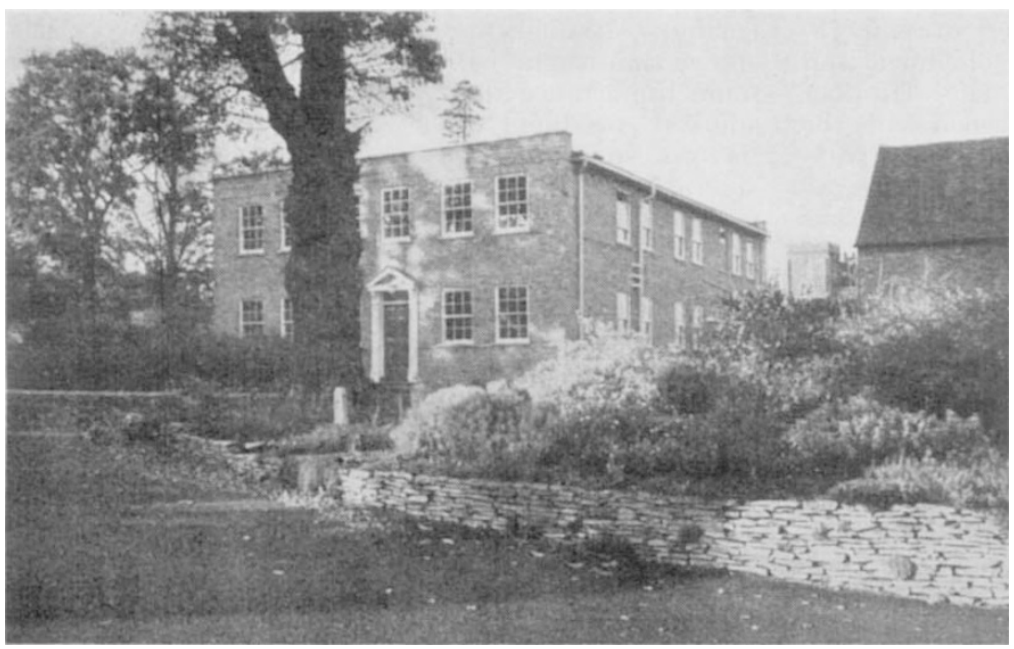

Fig. 1. Front view of the Shell Parasitology Building, Imperial College of Science and Technology students, a small teaching laboratory for undergraduates specializing in parasitology, and a photographic dark room. In the basement are three constant-temperature rooms separately controllable within the range $5^{\circ}-30^{\circ} \mathrm{C}$.

While research projects extend over the field of general parasitology (recent work has dealt with protozoal parasites of insects, and the bionomics of sheep trichostrongyle larvæ, for example), major prominence is given to nematology. The most pressing requirement was to house the postgraduate nematology course: it will now be possible to accommodate with comfort eight students, and at need up to twelve, instead of only four as hitherto.

This one-year course aims at giving a grounding in: (1) general nematology with an emphasis on plant-parasitic and soil-inhabiting species; (2) the principles of control by chemical and other means; (3) the art of experimentation. The course, the first of its kind in Great Britain, has a strong bias towards practical techniques and research methods. Of a total of fifteen students to date, ten have come from seven overseas countries, and it is hoped to maintain this overseas appeal, if only because plant eelworms are of great economic importance in tropical and subtropical lands.

The new laboratories are well equipped with such standard items as microscopes and calculating machines, and radiotracer equipment includes a versatile scaler with scintillation head, and monitor. Work is in progress with labelled chemical fumigants.

B. G. Peters

\section{THE HUMBER LABORATORY}

$\mathrm{T}$

HE Humber Laboratory of the Department of Scientific and Industrial Research at Hull held two open days during November 9-10. This establishment is a branch laboratory of the Torry Research Station, Aberdeen, and like its parent Station is concerned with research on the handling and process. ing of fish from the time of catching to retail sale. Since the Humber Laboratory was opened in 1952 it has dealt with an ever-increasing volume of work, particularly in applied research and in giving scientific information to the fish trade. The buildings have been extended twice during the short life of the station, and the recent open days marked the putting into service of a new block containing laboratories, library, and a lecture theatre.

The exhibits at the open days were not limited to the activities of the Humber Laboratory itself, but also covered the much wider range of subjects dealt with at the Torry Research Station. Prominent among these is the matter of freezing fish at sea. Poorer catches from present fishing grounds and the loss of some traditional grounds by the extension of territorial limits are encouraging longer voyages by British distant-water trawlers. This in turn means that the use of ice is no longer an adequate method of preserving all the catch in an edible condition. Freezing and cold storage is one obvious answer to the problem of preservation, but the successful application of this technique has required the cooperation of scientists and engineers trained in widely different disciplines. This was illustrated by exhibits which range from techniques of showing the damage to muscle cells during freezing, and of estimating the extent of denaturation of proteins in cold store, to a model of freezing plant designed to work on small ships in rough weather. The work of the Torry 